Dmitry I. Polyvyannyy (Ivanovo)

(iD) https://orcid.org/0000-0003-3680-5508

\title{
Dynasticity in the Second Bulgarian Tsardom and its Manifestations in Medieval History Writing*
}

$\mathrm{T}$ he idea of this essay comes both from the author's continuous studies in state ideology and cultural identity of the second Bulgarian Tsardom and from the spiritus loci - deeply rooted and rich dynastic traditions of the Polish medieval history carefully explored by many renowned Polish scholars and discussed in Polish historical editions. To some extent my intention was inspired by Ian Mladjov's thorough consideration of the Bulgarian monarchs' names and numbering published in "Studia Ceranea".

The notion of dynasticity used in the title of this essay needs some clarification. Though dynasticity became a conventional term in current medieval history research, it is understood in different ways first of all due to its core notion of dynasty. The origin of the term leads to the mythical Dynastes, Heracles' son from Erato, one of the fifty daughters of Thespios, king of Thespia. Later on in classic Greek this name had become a metaphor for mighty autocratic ruler, and accordingly its derivative dynasteia was synonymous to several forms of non-democratic statehood such as tyranny or monarchy ${ }^{2}$. Being often applied to ancient Syracuse

* The research is financially supported by the Russian Foundation for Basic Research, project № 17-01-00302-OGN.

${ }^{1}$ I.S.R. Mladjov, Monarchs' Names and Numbering in the Second Bulgarian State, SCer 5, 2015, p. 267-310. Keeping in mind Mladjov's sharp and contributive observations, conclusions and terminology, further on I follow the principle of Anglicizing the Bulgarian royal names (despite referring to and quoting other scholars' works) accepted by "Studia Ceranea". See the witty explanation of Anglicizing given by J. Fine: How could I say Ivan Alexander when his Greek counterpart was John Cantacuzenus? (see J.V.A. Fine, The Late Medieval Balkans. A Critical Survey from the Late Twelfth Century to the Ottoman Conquest, Ann Arbor 2009, p. IX-X). The monarchs are numbered in compliance with the Bulgarian academic tradition (seе И. Божилов, В. Гюзелев, История на средновековна България VII-XIV век, София 1999). The family and dynasty names follow Bulgarian plural forms Асеневци (Asens), Тертериевци (Terters), Шишмановци (Shishmans) etc., despite references and quotations.

${ }^{2}$ I. Jordović, Did the Ancient Greeks Know of Collective Tyranny?, Balc 36, 2006, p. 17-33 (21 f. 18). 
tyrannies, it was then used in the same sense for autocratic polities in early Byzantine texts. The closest to the époque of the second Bulgarian Tsardom is a passage in Anna Comnene's Alexiade where the female historian of royal pedigree mentioned "Samuel, the last of the Bulgarian dynasty (as Zedekiah of the Jewish)" Here her understanding of dynasty combined the hereditary sequence of rulers (though surprisingly wrong for the grand-granddaughter of the last true Tsar of Bulgaria before its fall, John Vladislav - 1015-1018) and monarchs governing a certain polity. Zedekiah, anointed by the Babylonian King Nebuchadnezzar II Tzar of Judah, was its last ruler (2Par 36, 9-11).

In scholarly literature dynasty denotes first of all the order of succession of the supreme power, as it existed in a medieval state ${ }^{4}$, along the lineage to descending offspring, siblings, those adopted or married to the persons of royal blood etc. It made it possible to support the continuity and stability of the monarchy. Since such a mechanism as a social fact both existed in social practice and was intellectually constructed, the dynasty could be a traditional and/or legally established institute, and/or a foundation myth of an imaged community. Both could co-exist as to establish and support (or, in some cases to invent and promote) the legitimacy of a currently existing rule. Thus dynasty in the Middle Ages was both a political and ideal pattern which was applied to reinforce and sustain the appropriate model of statehood.

Accordingly, dynasticity can be defined both as a characteristic of a monarchy and as its mental pattern. The latter leads to the understanding of dynasticity as a post factum concept created by history writers of medieval, modern and even contemporary times. Though it does not sound good enough from the linguistic point of view, the second Bulgarian Tsardom was definitely not as dynastic as medieval Polish Kingdom, while the latter sufficiently conceded in dynasticity to ancient China. While dynasticity was clearly expressed in medieval Polish history writing, its manifestations in the literary tradition of the second Bulgarian Tsardom are not as frequent and distinct, thus deserving a thorough search and adequate interpretation.

As soon as medieval Bulgarian history writing is concerned, it is necessary to mention that in the second Bulgarian Tsardom it was more of a trend than genre or profession ${ }^{5}$. In this essay the author, analyzing various medieval Bulgarian

\footnotetext{
${ }^{3}$ Annae Comnenae Alexias, VII, 3, 22-23, vol. I, rec. D.R. Reinsch, A. Kambylis, Berolini 2001 [= CFHB.SBe, 40], p. 210. English translation after V. TĂркоva-Zaimova, Bulgarians by Birth. The Comitopuls, Emperor Samuel and Their Successors According to Historical Sources and the Historiographic Tradition, Leiden-Boston 2017, p. 124.

${ }^{4}$ See J. Duindam, Dynasties, MWor 1, 2, 2015, p. 69-78; C. Pazdernik, Dynasty, idea of, Byzantine, [in:] Encyclopedia of Ancient History, Chichester 2012, p. 2243-2244.

${ }^{5}$ Seе В. Гюзелев, Българският книжовник-летописеи, през XIII-XIV век- опит за характеристика, [in:] Vis et sapientia. Studia in honorem Anisavae Miltenova. Нови извори, интепретаиии u подходи в медиевистиката, София 2016, р. 35-56.
} 
hagiographical texts, inscriptions and marginal notes, the Synodicon of the Bulgarian church and other pieces of history writing aims to reveal the dynastic concept of the Asens from the first three royal brothers - Theodore-Peter (1186-1197), John Asen I (1186-1196) and Kaloyan (1197-1207) - to John Alexander (1331-1371) and his successors. The second research track is defined by attempts to create and support a wholesome dynastic idea (or applying another methodological prism - that of a myth) with the means of medieval Bulgarian history writing. As far as the history writing is concerned, it is worth mentioning that in the second Bulgarian Tsardom it was not a separated and refined literary tradition but a component of hagiography, hymnography, inscriptions, charters etc. ${ }^{6}$

In the academic historiography of medieval Bulgaria dynasticity was often represented as a natural state of things, beginning with the first Bulgarian rulers from "the old dynastic family of Bulgars Dulo"7 and "the Krum's dynasty" in the $9^{\text {th }}-10^{\text {th }} \mathrm{cc}$., and ending with the commonly mentioned "Asen dynasty" or Asens (Асеневци). The "reign of Asens" is either represented at the limits of a hereditary line from John Asen I to John Asen III (1279-1280), extended to the whole period of the second Bulgarian Tsardom, or changed by the "dynasties" related to Asens - Terters and Shishmans after 1280. The "triadic" scheme of the rulers of the second Bulgarian Tsardom (Asens - Terters - Shishmans) appeared in the first academic History of Bulgaria by Konstantin Irećek ${ }^{9}$ and later on was developed by a vast majority of Bulgarian scholars. The unfinished History of the medieval Bulgarian state by Vasil N. Zlatarsky (1866-1935) considered Asens as a dynasty ruling in Tărnovo from the restoration of the Bulgarian Tsardom to $1280^{10}$. Against this background one of the few conceptually thinking Bulgarian medievalists of the $20^{\text {th }}$ c. Peter Mutafchiev (1883-1943), though mentioning "the time of Asens" and "the last Asens", underlined strange absence of continuity, sequence and regularity in the Bulgarians' political life ${ }^{11}$. The third volume of the fundamental History of Bulgaria, dedicated to the second Bulgarian Tsardom (in terms of that time - "second Bulgarian state") demonstrated a differentiation of views on dynasticity: while D. Angelov (1917-1996) and P. Petrov avoid this concept, V. Gjuzelev in fact returned to the "triadic" periodization of the monarchy stressing that with his enthronement Michael Shishman set the beginning of a new dynasty ${ }^{12}$.

\footnotetext{
${ }^{6}$ Sее Д. Полывянный, Культурная идентичность, историческое сознание и книжное наследие средневековой Болгарии, Москва 2018, p. 269-285.

${ }^{7}$ И. Божилов, В. ГюзЕлев, История на средновековна..., p. 75, 113.

${ }^{8}$ See the review of opinions and critics by Н. Хрисимов, За панонския произход на кан Крум и “Крумовата династия", Доб 32, 2017, p. 377-382.

${ }^{9}$ К. ИРечеК, История на България с поправки и добавки от самия автор, София 1978, p. 307-314.

${ }^{10}$ В.Н. ЗЛАТАРСКИ, История на бблгарската държава през средните векове, vol. III, Второ българско изарство. България при Асеневци (1187-1280), София 1940.

${ }^{11}$ П. МутАфчиев, Към философията на българската история. Византинизмбт в средновековна България, ФП 1, 1931, р. 28.

${ }^{12}$ История на България, vol. III, Втора българска държава, София 1982, p. 323.
} 
In the first volume of History of Bulgaria (1999) V. Gjuzelev and I. Bozhilov (1940-2016) divided "the time of Asens" into the periods of "Asens' patrimonium" (1185-1241), "establishment of dynastic law" (1241-1256) and rise "from usurpation to legitimism" (1256-1280). Meanwhile, in the next chapter of their common work Ivan Bozhilov called the Terters "the only dynasty which managed to break the rule of the Asens in Bulgaria" ${ }^{13}$, though their rule was interrupted by the reigns of Smilets (1292-1298) and his son John (1298-1299). The Terter family returned to the throne with Theodore Svetoslav (1299-1322) and lost it with the untimely death of his son George II Terter (1322-1323). According to the authors, the enthronement of Michael III Shishman (1323-1330) due to the decision of Bulgarian aristocracy meant not the beginning of the new dynasty, but restoration of old and glorious dynasty of Asens ${ }^{14}$, while the Tsar's tragic end in 1330 and the anointment of his son, whom he had with his Serbian wife Anna-Neda exiled in 1324, divided the bolyars into a "pro-Serbian party" led by Michael's brother Belaur and the "supporters of the Asen's dynasty" led by the despot John Alexander - grand-grandson of Theodora-Anna - daughter of John Asen II.

Ivan Bozhilov's outstanding prosopographical research on the family of Asens, following the approaches and terminology of Charles Du Cange and Ivan Dujcev separated the concepts of dynasty and family, plausibly connecting the direct lineage of the Asens' dynasty with Terters and Shishmans, broken in 1280, through their kinship with the offspring of the Asen family. The lineage of the Terters was represented as dynasty in the recent monographic research by Krasimir Krastev ${ }^{15}$. The same relates to the Shishmans often shown as a separate Bulgarian royal dynasty ruling after 1323 and subdivided by Mladjov into houses (understood by him as synonymous to dynasties or "genealogical groupings") of Shishmans and Sracimirs ${ }^{16}$. Some particular aspects of dynasticity are revealed in the studies of the monarchic institute in the second Bulgarian Tsardom ${ }^{17}$.

According to Jake Ransohoff, Bulgarian kingship after the extinction of the main Asenid line was essentially elective and non-hereditary succession became the norm in Late Medieval Bulgaria, in practice if not in theor $y^{18}$. This statement, though supported with persuasive statistics, does not exclude dynasticity as a factor of political life and important theme of history writing. Another conclusion, by Alexander

\footnotetext{
${ }^{13}$ И. Божилов, В. ГюзЕлев, История на средновековна..., p. 531.

${ }^{14}$ И. БОжилов, В. ГюзЕлев, История на средновековна..., p. 562.

${ }^{15}$ К. Кръстев, Българското иарство при династията на Тертеревци (1280-1321), Пловдив 2011. ${ }^{16}$ I.S.R. Mladjov, Monarchs' Names..., p. 274, 279, 284.

${ }^{17}$ Г. БАКАлов, Средновековният български владетел. Титулатура и инсигнии, София 1995; С. СТАнилов, Българската монархия през Средните векове, София 2003; И. Божилов, История на средновековна България, vol. II, Християнска България, София 2017.

${ }^{18} \mathrm{~J}$. Ransohoff, All the Tsar's Men: Reflections on Power and Society in Asenid Bulgaria (1257-1393), [in:] Landscapes of Power. Selected Papers from the XV Oxford University Byzantine Society International Graduate Conference, Oxford 2014, p. 253-273, 262.
} 
Madgearu, that the succession to power in the Second Bulgarian Empire was a matter of election by various groups of boyars, and not of dynastic legitimacy ${ }^{19}$ develops what Ransohoff rightly states, but looks even more rigorous.

The history of royal succession in the second Bulgarian Tsardom together with hereditary ascension included marriage and adoption, co-ruling and regency, proclamation and election. According to George Akropolites, when in 1257

the Bulgarian realm was left without a legitimate heir, the leading men met in deliberation and determined to accept Constantine, the son of Toichos, to rule them. But so that he might appear to govern by inheritance, they sent an embassy to the emperor Theodore requesting that he send his eldest daughter, who was named Eirene, for union with Constantine, son of Toichos, and be joined in lawful wedlock, as she was a granddaughter of the former ruler of the Bulgarians, John Asan, and was fitted for this realm. ${ }^{20}$

The only succession of three generations - from the first Asens to John Asen II - was interrupted by Boril's reign in 1207-1218. Only four uninterrupted royal lineages of two generations took place from 1186 to 1395 - from John Asen II to Kaliman Asen in 1241; from Theodor Svetoslav to George Terter II in 1322; from Michael III Shishman to John Stephan in 1331 (though interrupted with internecine); and from John Alexander to John Shishman in 1371. The sons of the last Bulgarian Tsars John Shishman (1371-1395) and John Sracimir (1365-1396) - Prince Fruzhin and Tsar Constantine - lost their domains, Tărnovo and Bdin, conquered in $1395-1396$ by Bayezit I Yildirim $(1389-1402)^{21}$.

There were three cases of passing the Bulgarian throne from brother to brother (from John Asen I to his former co-ruler Theodore-Peter in 1196; from John Asen I to Kaloyan in 1197; from Kaliman Asen to Michael Asen II in 1246). One was the succession between uncle and nephew (from Kaloyan to Boril in 1207). The other transitions were made through election (like Constantine Tikh, Michael Shishman III or John Alexander), self-proclamation followed by marriage with the royal person (like Ivailo) etc. The right of the monarchs to the throne was justified by their real or supposed descent from the first Asens or a marriage with a princess of Asen origin. It is worth mentioning that such marriages could take place both before the royal ascension (as in the case of Constantine Tikh and Eirene Lascarina Asenina) and after it (as in the case of Ivailo). At the same time, this way of dynastic continuity being useful in throne ascension, it was not necessary further on, since

\footnotetext{
${ }^{19}$ A. Madgearu, The Asanids. The Political and Military History of the Second Bulgarian Empire (1185-1280), Leiden-Boston 2017, p. 244.

${ }^{20}$ Georgii Acropolitae Historia, 73, [in:] FGHB, vol. VIII, ed. М. Войнов et al., София 1972 (cetera: Georgii Acropolitae Historia), p. 205. English translation after George Akropolites, The History, ed. et trans. R. MACrides, Oxford 2007 [= OSB], p. 334.

${ }^{21}$ П. ПАвлов, И. Тютюнджиев, Българската държава и османската експанзия (1369-1422), Велико Търново 1995, р. 25-38.
} 
George Terter I (1280-1292) left his second wife Kyra Maria Asenina and returned to the first one soon after the coronation ${ }^{22}$.

In medieval Bulgarian and Byzantine sources the notions of royal origin and royal blood stress the legitimacy of naturally inherited throne succession. A prominent Bulgarian writer of the $10^{\text {th }} \mathrm{c}$. John Exarch in the fourth charter of his Hexameron on the Divine creation of the celestial bodies opposed astrology with dynastic arguments:

In many countries there are rulers by birth (властели по ९одоу) - Tsars, Princes and Kings [who rule] not due to compliance with Zodiac, nature of stars and their impact, but by kinship and heritage order and significance. And son comes to father's place, and brother - after brother ${ }^{23}$.

Giving as examples of succession David's kin in Judah, Cyros' in Persia and Candaulos' in Lydia, John Exarch concludes:

How could there be so many cases when a son accepts his father's power? Can it be, that in all such cases the forces of Zodiac came together, and stars created a configuration for this lord, so that the one who was born at this moment gets the Tsar's power

and reinforces the statement with his own argument:

Among the Bulgarians princes from the beginning rule by birth after their fathers and after their brothers. The same, as it is heard, happens among Khazars ${ }^{24}$.

This text is particularly important to understand the traditional Bulgarian view on dynasticity and its representation in the history writing. John Exarch begins with history cases classical for him and considers them against the background of his own knowledge of Bulgarian traditions and oral information on Khazars.

Special attention was paid to the same problem by Michael Psellos, whose informant on the events of Bulgarian uprising was one of its leaders - Alousian, son of the last tsar of the first Bulgarian Tsardom John Vladislav. Psellos' story of recognizing Alousian as a man of royal descent in contrast with the impostor Delyan-Dolianos, who adopted the name of the first Bulgarian Tsar recognized by

${ }^{22}$ К. Кръстев, Българското..., p. 49-50.

${ }^{23}$ Шестоднев, составленный Иоанном Ексархом Болгарским по харатейному списку Московской Синодальной библиотеки слово в слово и буква в букву, ЧИОИДР 3, 1879, f. 130a. See Russian translation in: Шестоднев Иоанна экзарха Болгарского, еd. Г.С. БАрАнковА, Москва 1998, p. 736. Bulgarian translation in: ЙоАн ЕкзАрх, Шестоднев, trans. et ed. Н. Кочев, София 1981, p. 163. English translation: K. Peткоv, The Voices of Medieval Bulgaria. Seventh-Fifteenth Century. The Records of a Bygone Culture, Leiden-Boston 2008 [= ECEEMA, 5], p. 90. The English translation above is mine using as reference the above mentioned translations.

${ }^{24}$ Шестоднев, составленный Иоанном Ексархом..., f. 1306. 
Byzantium, Peter (927-969), is full of topoi characteristics, usual for narratives on imposture and recognition of a person of royal blood. According to Psellos' story, Alousian found among the rebels a man who had known him in childhood and to fully assure him about his descent demonstrated to him his "secret sign" - dark patch on the right elbow, with a thick tuft of rough hair grown over it ${ }^{25}$. The story itself has a lot of parallels especially in early modern Russian history, but the "royal signs" here definitely mean that divine predestination has priority over human choice. Alousian's rival Delyan, as it is shown in the illuminated Madrid manuscript of John Scylitses' Chronicle, was proclaimed Tsar under the name of Peter by being raised on a shield by the insurgents - a well-known military rite in Byzantium ${ }^{26}$.

The priority of the Divine will over heredity or kinship in one's ascension to the Bulgarian throne is clearly expressed in formulas of two Tsars' charters of the $13^{\text {th }}-14^{\text {th }}$ c.:

\begin{abstract}
After the death of my Tsardom, whoever might be the heir to my Tsardom, be it among the beloved children of my Tsardom, or among the relatives of my Tsardom, or anyone else chosen by God to sit on the throne of my Tsardom, anyone among the Orthodox Christians ${ }^{27}$, or whoever the Lord God, the Eternal Tsar, wills to place on the throne of my Tsardom, be it the most beloved son of my Tsardom, or [some] of the brothers and relatives of my Tsardom...28
\end{abstract}

In the $14^{\text {th }}$ c. copy of the earlier Constantine Tikh's charter to the Monastery of St. George the Fast, in the same case an indefinite formula is used ${ }^{29}$ - "whoever God wills to put on the throne of my Tsardom or some of the relatives of my Tsardom". Anyway, the limited number of such acts does not allow for more founded general conclusions.

Having in mind that the core Bulgarian political practices had been formed before Constantinople was reconquered by Michael VIII Palaeologos in 1261,

\footnotetext{
${ }^{25}$ Michel Psellos, Chronographie ou histoire d’un siècle de Byzance (976-1077), IV, 46-48, vol. I, ed. É. Renauld, Paris 1926, p. 80; Michaelis Pselli Chronographia, [in:] FGHB, vol. VI, ed. M. Войнов et al., София 1965, p. 97-98; English translation in: V. TĂркоva-ZAimova, Bulgarians by Birth..., p. 55-56.

${ }^{26}$ See the image in the digital copy of the Madrid Scylitses manuscript at the World Digital Library https://www.wdl.org/en/item/10625/ [21 IV 2019].

${ }^{27}$ John Alexander's charter of 1347 to the Monastery of St. Nicholas in Oryakhovo (Г.А. Ильинский, Грамоты болгарских изарей, [in:] Древности. Труды Славянской комиссии Московского Императорского Археологического общества, vol. V, Москва 1911, p. 25; А. ДАскалова, М. РАЙковА, Грамоти на българските изаре, София 2005, p. 42-43). English translation after K. Реткоv, The Voices of Medieval Bulgaria..., p. 499.

${ }^{28}$ John Shishman's charter of 1378 to Rila Monastery (Г.А. Ильинский, Грамоты ..., p. 28; А. ДАскАлова, М. РАйкова, Грамоти..., p. 46). English translation after K. Реткоv, The Voices of Medieval Bulgaria..., p. 506.

${ }^{29}$ Г.А. ИльИНСКИЙ, Грамоты..., p. 19; А. ДАСКАЛОвА, М. РАЙКОвА, Грамоти..., p. 35. English translation after K. Pеткоv, The Voices of Medieval Bulgaria..., p. 493-494.
} 
it is worth recalling the evaluation retroactively given to the Epirote ruler Theodore Lascaris II (1254-1258) by the Nicaean and later Palaeologian historian and statesman George Akropolites (1217-1282):

Being naturally unsuited to the institutions of the Imperial office, he handled matters in a Bulgarian or, rather, barbarian fashion for he did not understand hierarchy or protocol or the many ancient customs which have been established in the palaces ${ }^{30}$.

It seems that for Akropolites the Bulgarian way of handling matters was something in between Byzantine and Barbarian ones as a kind of their synthesis.

A characteristic trait of Acropolites' vision of the Bulgarian monarchs is his

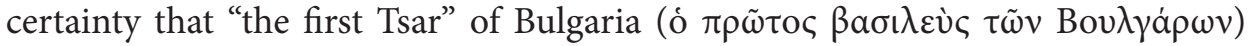
was Asan - John Asen I. Acropolites ignores the proclamation of Theodore-Peter as Tsar, so vividly described by Choniates, stating that

Asan had two brothers, of whom one was called Peter, the other John. Asan kept John with him, but Peter he ordered to rule over a portion which he cut from his own province... Asan ruled over the Bulgarian race as emperor for nine years when he was murdered by his first cousin Ivanko; he immediately died. Then John, Asan's brother, ruled over the race as emperor because the Bulgarians did not want to raise Peter to the royal office, and Asan's son John was not yet of age. ${ }^{31}$

It looks that Akropolites' account could be based upon the version that was contemporary to him, i.e. the Bulgarian version from the beginning of the Second Bulgarian Tsardom, so his understanding of the Asens' dynasty drew a direct line from the first Asen to John Asen II, giving the latter his "highest regard", as Macrides underlines. The first meanly dated Bulgarian source mentioning the connection between John Asen II and his father is the famous inscription in the Laura of St. Forty Martyrs in Tărnovo: "I, John Asen, in Christ God faithful Tsar and autocrat of the Bulgarians, son of the old Tsar Asen..." ${ }^{32}$ The same dynastic manifestation is present in the Bulgarian additions to the Slavic translation of Constantine

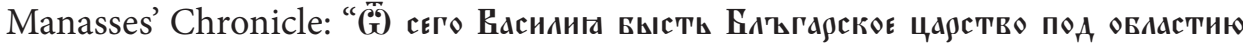

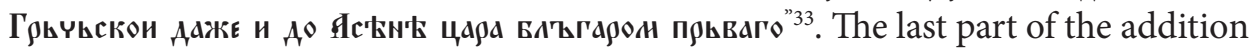
was translated "To Asen the First, Tsar of Bulgarians" by Ivan Dujchev - in Bul-

\footnotetext{
${ }^{30}$ Georgii Acropolitae Historia, 21, p. 158. R. MACRIDEs, p. 162 connects "Bulgarian" with the title of Archbishop of Bulgaria Demetrios Chomatenos, who anointed Theodore Comnene Emperor.

${ }^{31}$ Georgii Acropolitae Historia, 12, p. 154, English translation after R. MACRIDEs, p. 137.

${ }^{32}$ И. Дуйчев, Стара българска книжнина, vol. II, Книжовни и исторически паметници от второто Българско иарство, София 1944, p. 38; English translation is after K. Pеткоv, The Voices of Medieval Bulgaria..., p. 425.

${ }^{33}$ Среднеболгарский перевод хроники Константина Манасии в славянских титературах, ed. М. Салмина et al., София 1988, p. 234; English translation is after K. Реткоv, The Voices of Medieval Bulgaria..., p. 454.
} 
garian, by Kiril Petkov - in English, and by myself - in Russian ${ }^{34}$, while Ivan Buyukliev in his translation in verse omitted "the first" at all ${ }^{35}$. In the context of all the above mentioned I would offer another translation: "Asen, the first Tsar of Bulgarians", having in mind above all two circumstances. First, no Bulgarian Tsar in the $13^{\text {th }}-14^{\text {th }}$ cc. bearing the same name as his predecessor was numbered in medieval texts - in such cases the term "old" was used to differentiate between two namesakes (John Asen or George Terter) ${ }^{36}$. Second, in the narrow context of this addition to the Chronicle of Manasses Asen is represented as the first Tsar after the Bulgarian Tsardom's long being "under the Greek power", and in the wider context of all the additions as a whole his reign is a milestone in the "prehistory" of the Bulgarian "new Rome" glorified in the other addition to the Manasses Chronicle ${ }^{37}$.

It looks that the name and reign of John Asen I were used to create the only dynastically ordered narrative of the second Bulgarian Tsardom, reflected in the above quoted note in Slavic by Manasses and in his memory in the Synodicon of the Bulgarian church: "To John Asen Tsar Belgun, who liberated the Bulgarian people from Greek slavery" ${ }^{38}$. Here John Asen I is represented as the founding person of the "new", as distinct from "ancient", dynasty of the Bulgarian Tsars and the cornerstone of their sequence. Theodore-Peter and Kaloyan are mentioned as his brothers, and Boril - as their sister's son. The next after him, "the great and pious Tsar John Asen" is called "son of the old Tsar Asen" in the narrative on the restoration of the Bulgarian Patriarchate ${ }^{39}$. In his turn, John Asen II became the cornerstone for the next generation of the dynasty - his sons Kaliman and Michael, brother Alexander and cousins Alexios Slav and Strez.

The earlier history of shaping the dynastic history of Asens can be reconstructed on the basis of hagiographic texts connected with the transfer of St. John of Rila’s relics from Sredets-Sofia to Tărnovo, usually dated 1195. The "historical tales" on this transfer were included in four fragments of the brief and expanded Vitae of the saint during the $13-14^{\text {th }} \mathrm{cc}$. The shortest one belongs to the so called

\footnotetext{
${ }^{34}$ И. Дуйчев, Стара българска книжнина, vol. II..., p. 102; K. Peткоv, The Voices of Medieval Bulgaria..., p. 454; Д. Полывянный, Культурная идентичность..., p. 445. Mladjov translates it in between the two options: "even to the emperor of the Bulgarians Asen, the first" (I.S.R. MLadjov, Monarch' Names..., p. 267).

${ }^{35}$ Стара българска титература, vol. III, Исторически съчинения, еd. И. Божилов, София 1983, p. 327.

${ }^{36}$ Българската литература и книжнина през ХІІІ век, еd. И. Божилов, С. КожухАРов, София 1987, p. 55, 57, 112, 114, 200, 201.

${ }^{37}$ Seе М. КАЙмаКАмова, Власт и история в средновековна България, VII-XIV век, София 2011, p. 293-296, who demonstrates the process of integration of the Bulgarian additions into Manasses' chronicle so that they form a parallel narrative aimed to follow the transformation of Bulgaria into new Orthodox Empire against the background of the World and Byzantine histories.

${ }^{38}$ Борилов синодик. Издание и превод, еd. И. Божилов, А. ТотомановА, И. Билярски, София 2010, p. 150, English translation p. 352.

${ }^{39}$ Ibidem, p. 156, 353.
} 
Norov's Prologue, usually dated $13^{\text {th }} \mathrm{c}$. The manuscript itself is attributed to the Pchinya monastery connected to one of St. John's followers - St. Prokhor. The fragment on translatio is brief and mentions "the faithful Tsar Asen" (blagovernyj Tsar Asen), describing shortly the transfer of the relics to "city of Trapesitza", where they were "still laying" likely created in Athos in the second half of the $13^{\text {th }} \mathrm{c}$. It expands the description by talking about "the new offshoot, the Christ-loving Tsar Asen, who renewed the Bulgarian people $\mathrm{e}^{41}$ " and contains detailed though traditional and topoi-laden description of the relics' arrival in Tărnovo. The third passage is part of the Sofia Versed Prologue dated second half of the $14^{\text {th }} \mathrm{c}$. Only here is the Christian name of the first Asen mentioned: "Christ-loving Tsar Asen, whose name in the holy baptism was John" ${ }^{42}$. The tale on the relics in the Vita written by Patriarch Euthymius of Tărnovo by the last quarter of the $14^{\text {th }} \mathrm{c}$. calls Asen "the most pious Tsar Asen, called in the holy baptism John" ${ }^{\prime 3}$.

Though all four texts originate from different South Slavic lands and centers, and are not parts of a fully continuous and interconnected literary tradition it is highly possible that they reflect the gradually forming "founding myth" of the Asens dynasty which was not fully complete even in the last decades of the second Bulgarian Tsardom.

Returning to the memories of the Bulgarian Tsars in the Synodicon of the Bulgarian church we can find other traits of dynasticity though their full repertoire is not saved. After the first complex of royal memories which form an image of a mighty house of Asens springing from the root of "old" John Asen and strengthened by his "great" son John Asen, a big part of the memories is lost. The elder Palauzov's copy from the $14^{\text {th }} \mathrm{c}$. contains only the beginning of the memory of Constantine Tikh Asen, "pious and Orthodox Tsar" ${ }^{4}$, while the textual continuation is saved in Drinov's copy of the $16^{\text {th }} \mathrm{c}$. Here the memories go on with "pious Tsar George Terter the Old" (sic!), "virtuously pious Tsar Shishman", "pious Tsar Theodor Svetoslav", "pious Tsar George Terter" and his kin, and are concluded with memories of "pious Tsar Michael" and "Tsar John Stephan, the son of the pious Tsar Michael" $"$.

\footnotetext{
${ }^{40}$ Българската литература и книжнина.., р. 50.

${ }^{41}$ Ibidem, p. 50.

${ }^{42}$ Ibidem, p. 52. Seе И. ЛАзАРов, Владетелското име „Йоан” и култбт към св. Йоан Рилски в държавно-политическата идеология на второто Българско изарство, [in:] Светогорска обител Зографб, vol. III, ed. В. ГюзЕлев, София 1999, p. 90-98.

${ }^{43}$ Werke des Patriarchen von Bulgarien Euthymius (1375-1393) nach den besten Handschriften, ed. E. KaŁUŽNiaCKi, Wien 1901, p. 23.

${ }^{44}$ Борилов синодик..., p. 161, 354.

${ }^{45}$ Ibidem, p. 162, 354-355.
} 
The memory of John Stephan (1330-1331) is followed on the same folio of Drinov's copy by a remarkable text which, as far as I am informed, had not been an object of special consideration:

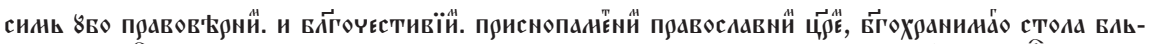

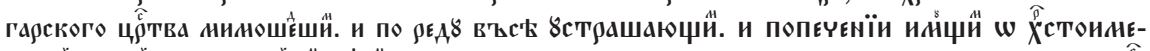

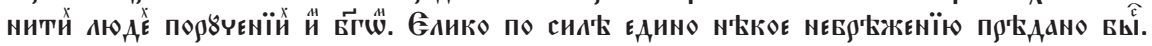

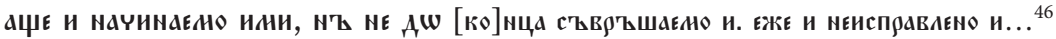

In two English translations, by Kiril Petkov and Maria Paneva (the last one follows accurate Bulgarian translation of the Synodicon done by Anna-Maria Totomanova), this text acquires different meanings. Petkov takes the text as another memory, though an unfinished one:

To these, then, righteous, pious, of blessed memory, and Orthodox tsars, who ruled over the God-protected throne of the Bulgarian Tsardom and arranged everything in good order and took good care of the people who carry the name of Christ who have been entrusted to them by God... ${ }^{47}$

Paneva's translation is, to my mind, more adequate and keeps the grammar of the piece (here I am making a couple of slight corrections in it):

The Orthodox, pious and ever-memorable kings who passed by the God-guarded throne of the Bulgarian kingdom, who ruled according to the order and who took care of the people, whom God entrusted to them, bearing the name of Christ. I might have as far as I am capable also neglected some of the deeds they had started but never finished and accomplished... ${ }^{48}$

If this translation is right, the note resembles the formula humilitatis usual for a medieval writer and could be followed by the lost appeal to the readers to be merciful to the scribe. In this case its connection with the above mentioned complex of memories could mean that in addition to being used for church commemoration it could be used for reading and listening. Another possible interpretation is that the unfinished text explained the absence of some names among the Tsars' memories.

For the theme of our essay the core meaning of the commemorative text is valuable. The mortal Tsars changed each other on the Bulgarian Throne, eternal against their short earthly lives. The word "ниношєдши" was used in the same sense

${ }^{46}$ Ibidem, p. 162, see the copy of the manuscript page in: М. Попруженко, Синодик ияаря Борила, София 1926, p. 4.

${ }^{47}$ K. Petкov, The Voices of Medieval Bulgaria..., p. 256.

${ }^{48}$ Борилов синодик..., р. 355. 
in John Alexander's charter to St. Nicholas monastery in Oryakhovo (1347): Like those passed Tsars, holding the scepter of the Bulgarian Tsardom (гкожє и схчии

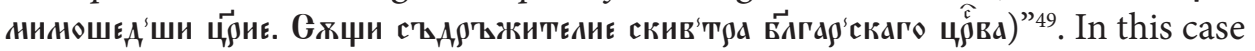
it definitely means 'passed forever', corresponding with the unfinished commemorative record of the Synodicon.

Another remarkable use of this word in a similar context - drawing on the oppositions of temporary versus permanent and present versus past - was registered in the records of the church court trial of Maximos Trivelis (Maxim the Greek) in Moscow in 1532. The learned monk was accused of heresy and asked by the court: Why did you write and tell others that Christ's sitting to the right of the

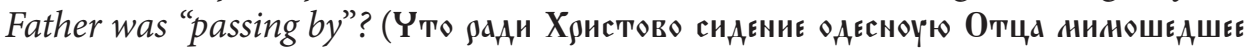
писаль єси и говорил? $)^{50}$. Maxim's response in Greek was recorded as follows: Passing by and passed as Adam's life in the paradise and sitting out of it is as passed as Christ's sitting to the right of the Father has passed (МиношедШев и ниноүвшев ако

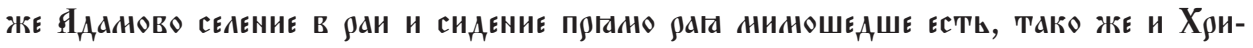

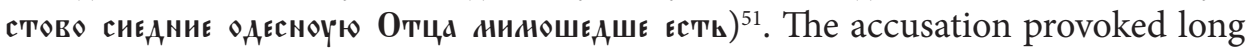
dispute and finally Maxim agreed that he had made a translation error, but there was no dogmatic deviation. Evgeny Golubinsky expressed his doubts about the dispute's essence ${ }^{52}$. Having in mind, that the word "mimošedši" is used in many popular Slavic prayers, liturgical readings and hymns, it is possible to suppose that the most general sense of this word leads to definitions like temporary, unstable, or ultimately passed.

This way the expression "mimošedšim Carems" in the above quoted passage of the Synodicon juxtaposes the temporary Tsars to the eternal Tsardom, the Sceptre of which they had received for limited time when they occupied the Bulgarian throne. The latter is often called in Bulgarian texts of the $13^{\text {th }}-14^{\text {th }} \mathrm{cc}$. Tabernacle (skinia). The Throne once granted to the Bulgarian Tsars was represented as eternal Divine gift against the background of numerous changes in the Bulgarian political being ${ }^{53}$. This understanding of dynasticity corresponds with the above quoted Peter Mutafchiev's words. Aimed to manage the row of violent and sudden ascensions and dizzy fall $5^{54}$ dynasticity was among the few means to proclaim and provide the desired stability which otherwise was lacking in the second Bulgarian Tsardom. Only few of the Bulgarian Tsars could represent stability and continuity in person, and therefore dynasticity was clearly relevant.

\footnotetext{
${ }^{49}$ Г.А. ИльИнсКИЙ, Грамоты ..., p. 24; А. ДАСКАловА, М. РАЙКОвА, Грамоти..., p. 41; К. Реткоv, The Voices of Medieval Bulgaria..., p. 497-498 omits this word.

${ }^{50}$ Прение Даниила, митрополита Московского и Всея Руси с иноком Максимом Святогорием, ЧИОИДР 7, 1847, 7, p. 1.

${ }^{51}$ Ibidem.

${ }^{52}$ Е. Голувинский, История русской Церкви, vol. II, Москва 1900, p. 712-713.

${ }^{53}$ Българската литература и книжнина..., р. 50, 52.

${ }^{54}$ П. МутАфчиев, Кбм филособията..., р. 58.
} 


\section{Bibliography}

\section{Primary Sources}

Annae Comnenae Alexias, vol. I-II, rec. D.R. ReInsch, A. Kambylis, Berolini 2001 [= Corpus fontium historiae byzantinae. Series Berolinensis, 40].

Bălgarskata literatura i knižnina prez XIII vek, ed. I. Božılov, S. Kožucharov, Sofija 1987. Borilov sinodik. Izdanie i prevod, ed. I. BožIlov, A. Totomanova, I. Biljarski, Sofija 2010.

Daskalova A., Rajkova M., Gramoti na bălgarskite care, Sofija 2005.

DuJČEv I., Stara bălgarska knižnina, vol. II, Knižovni i istoričeski pametnici ot vtoroto Bălgarsko carstvo, Sofija 1944.

George Akropolites, The History, ed. et trans. R. Macrides, Oxford 2007 [= Oxford Studies in Byzantium].

Georgii Acropolitae Historia, [in:] Fontes graeci historiae bulgaricae, vol. VIII, ed. M. VoJnov et al., Sofija 1972, p. 151-213.

IL'Inskij G.A., Gramoty bolgarskich carej, [in:] Drevnosti. Trudy Slavjanskoj komissii Moskovskogo Imperatorskogo Archeologičeskogo ob̌̌čestva, vol. V, Moskva 1911.

JoAn EkzARCh, Šestodnev, trans. et ed. N. KočEv, Sofija 1981.

Michaelis Pselli Chronographia, [in:] Fontes graeci historiae bulgaricae, vol. VI, ed. M. Vojnov et al., Sofija 1965, p. 93-116.

Michel Psellos, Chronographie ou histoire d’un siècle de Byzance (976-1077), vol. I-II, ed. É. Renauld, Paris 1926-1928.

Petкov K., The Voices of Medieval Bulgaria. Seventh-Fifteenth Century. The Records of a Bygone Culture, Leiden-Boston 2008 [= East Central and Eastern Europe in the Middle Ages, 5].

Popruženko M., Sinodik carja Borila, Sofija 1926.

Prenie Danila, mitropolita Moskovskogo i Vseja Rusi s inokom Maksimom Svjatogorcem, "Чтения в Императорском Обществе Истории и Древностей Российских при Московском Университете" / "Čtenija v Imperatorskom Obščestve Istorii i Drevnostej Rossijskich pri Moskovskom Universitete" 7, 1847.

Srednebolgarskij perevod chroniki Konstantina Manasii v slavjanskich literaturach, ed. M. SALmina et al., Sofija 1988.

Stara bălgarska literatura, vol. III, Istoričeski Săčinenija, ed. I. BožIlov, Sofija 1983.

Šestodnev, sostavlennyj Ioannom Eksarchom Bolgarskim po charatejnomu spisku Moskovskoj Sinodalnoj biblioteki slovo v slovo i bukva v bukvu, "Чтения в Императорском Обществе Истории и Древностей Российских при Московском Университете” / “С̌tenija v Imperatorskom Obščestve Istorii i Drevnostej Rossijskich pri Moskovskom Universitete” 3, 1879.

Šestodnev Ioanna ekzarcha Bolgarskogo, ed. G.S. BARAnkova, Moskva 1998.

TĂркоva-Zaimova V., Bulgarians by Birth. The Comitopuls, Emperor Samuel and Their Successors According to Historical Sources and the Historiographic Tradition, Leiden-Boston 2017.

Werke des Patriarchen von Bulgarien Euthymius (1375-1393) nach den besten Handschriften, ed. E. KaŁUžNiaCKI, Wien 1901. 


\section{Secondary Literature}

BaKalov G., Srednovekovnijat bălgarski vladetel. Titulatura i insignii, Sofija 1995.

Božılov I., Istorija na srednovekovna Bălgarija, vol. II, Hristijanska Bălgarija, Sofija 2017.

BožIlov I., Gjuzelev V., Istorija na srednovekovna Bălgarija VII-XIV vek, Sofija 1999.

Duindam J., Dynasties, “Medieval Worlds. Comparative and Interdisciplinary Studies” 1, 2, 2015, p. 69-78.

Fine J.V.A., The Late Medieval Balkans. A Critical Survey from the Late Twelfth Century to the Ottoman Conquest, Ann Arbor 1987.

GJUZELev V., Bălgarskijat knižovnik-letopisec prez XIII-XIV vek - opit za harakteristika, [in:] Vis et sapientia. Studia in honorem Anisavae Miltenova. Novi izvori, intepretacii i podhodi v medievistikata, Sofija 2016, p. 35-56.

Golubinskij E., Istorija russkoj Cerkvi, vol. II, Moskva 1900.

Hrisimov N., Za panonskija proizhod na kan Krum i "Krumovata dinastija”, “Добруджа" / "Dobrudža" 32, 2017, p. 377-382.

IREČEK K., Istorija na Bălgarija s popravki i dobavki ot samija avtor, Sofija 1978.

Istorija na Bălgarija, vol. III, Vtora bălgarska dăržava, Sofija 1982.

Jordović I., Did the Ancient Greeks Know of Collective Tyranny?, "Balcanica. Annual of the Institute for Balkan Studies" 36, 2006, p. 17-33.

Kajmakamova M., Vlast i istorija v srednovekovna Bălgarija, VII-XIV vek, Sofija 2011.

KRĂSTEv K., Bălgarskoto carstvo pri dinastijata na Terterevci (1280-1321), Plovdiv 2011.

Lazarov I., Vladetelskoto ime "Joan" i kultăt kăm sv. Joan Rilski v dăržavno-političeskata ideologia na vtoroto Bălgarsko carstvo, [in:] Svetogorska obitel Zograf, vol. III, ed. V. GJUZELEv, Sofija 1999, p. 90-98.

Madgearu A., The Asanids. The Political and Military History of the Second Bulgarian Empire (1185-1280), Leiden-Boston 2017.

Mladjov I.S.R., Monarchs' Names and Numbering in the Second Bulgarian State, "Studia Ceranea. Journal of the Waldemar Ceran Research Center for the History and Culture of the Mediterranean Area and South-Eastern Europe" 5, 2015, p. 267-310.

Mutafčıev P., Kăm filosofijata na bălgarskata istorija. Vizantinizmăt v srednovekovna Bălgarija, “Философски преглед" / "Filosofski pregled" 1, 1931, p. 27-36.

PAvlov P., Tjutjundžıev I., Bălgarskata dăržava i osmanskata ekspanzija (1369-1422), Veliko Tărnovo 1995.

Pazdernik C., Dynasty, idea of, Byzantine, [in:] Encyclopedia of Ancient History, ed. R. BAgnall et al., Chichester 2012, p. 2243-2244.

Polyvyannyy D., Kul'turnaja identičnost', istoričeskoe soznanie i knižnoe nasledie srednevekovoj Bolgarii, Moskva 2018.

Ransohoff J., All the Tsar's Men: Reflections on Power and Society in Asenid Bulgaria (1257-1393), [in:] Landscapes of Power. Selected Papers from the XV Oxford University Byzantine Society International Graduate Conference, Oxford 2014, p. 253-273.

Stanilov S., Bălgarskata monarhija prez Srednite vekove, Sofija 2003.

Zlatarski V.N., Istorija na bălgarska dăržava prez srednite vekove, vol. III, Vtoro bălgarsko carstvo. Bălgarija pri Asenevci (1187-1280), Sofija 1940. 


\begin{abstract}
Analyzing various medieval Bulgarian hagiographical texts, inscriptions and marginal notes, as well as the Synodicon of the Bulgarian church and other evidence, the author aims to reveal the dynastic concepts of the second Bulgarian Tsardom (1186-1396) and literary attempts to create and support a complex dynastic idea with the means of medieval Bulgarian history writing. Such attempts were connected with two core ideas. Firstly, the state's foundation was represented as a personal merit of two Asens - father and son. Asen "the Old" adopting the throne name John marked the beginning of the Asens' Tsardom liberating the Bulgarians from "the Greek slavery" and transferring to his stronghold Tărnovo from Sredets - the center of the Byzantine power over Bulgaria - the relics of St. John of Rila. John Asen "the Great", his son, strengthened the Tsardom with his victories, returned the status of Patriarchy to the Bulgarian church and brought the relics of St. Parasceve to the capital Tărnovo. Secondly, the literary tradition shaped the image of the Bulgarian Tsardom as an ever-lasting Empire whose enduring attributes - Sceptre and Throne - were given by God to change the mortal monarchs.
\end{abstract}

Keywords: dynasty, dynasticity, second Bulgarian Tsardom, history writing, Asens, Terters, Shishmans.

Dmitry I. Polyvyannyy

Ivanovo State University

ul. Ermaka 39

153025 Ivanovo, Russia

dipol53@gmail.com 